\title{
Undocumented Mexican Immigrants in Adult ESL Classrooms: Some Issues to Consider
}

\author{
Sheri Jordan
}

\begin{abstract}
With anti-immigrant sentiments permeating the media, policy, and public discourse throughout the United States, little room seems to exist for understanding what drives Mexican migrants northward. However, while acknowledging the historical conditions leading to US immigration policy, negative discourses and stereotypes in the American media and public, continuing Mexican migration in spite of great sacrifice, and the choices of individuals to migrate to the US, adult ESL educators need a framework as they encounter these students in the classroom. This framework combines Freire's "pedagogy of the oppressed" with a transformative pedagogy that relinquishes deficit models and invites student knowledge into the classroom.
\end{abstract}

\section{Introduction}

The City/La Ciudad, filmed over a 6-year period by David Riker (1999), offers "a moving tribute to the struggles and hopes of a group of new Latin American immigrants facing the harsh realities of urban America" (DVD case description). Several black and white cameos of the lives of first-generation immigrants to New York City facing daunting odds depict the bleakness of their situations and pose disturbing questions for American viewers watching comfortably from soft living room couches: Why do these immigrating hopefuls make such great sacrifices to live such second-class lives in our urban centers? Why would grown men fight each other for a hard labor job paying 15 cents per brick cleaned, only to see a comrade die tragically when a wall collapses and the boss is nowhere to be seen to assist? Why would a young woman stay in the US for four years, never once going back to Mexico to see her family, choosing to remain instead in cold American urbania for the sake of sending money home? Why would a tuberculous puppeteer spurn the homeless shelters and choose instead to live in his car with his daughter, who cannot get into a school because he has no proof of residential address? The tragedies abound and, from the reports of my own immigrant contacts in California, where the most immigrants and illegal immigrants to this nation flock (Camarota, 2007), this movie depicts la realidad.

I open my paper with this movie not only for dramatic effect, but because I have heard similar stories from Mexican, Latin and South American students and friends. Migration through our southern border is not only a hot topic in the US now, but has been for decades. Teachers need to familiarize themselves with their students' histories and cultures and the sociopolitical context of immigration, 
language, and education policies (Nieto \& Bode, 2008; Menard-Warwick, 2005). This paper seeks to introduce some of this historical and sociopolitical context, as well as to recommend critical pedagogical approaches that tap into adult ESL students' funds of knowledge and move beyond deficit models of immigrant education.

\section{The "Mexican Problem": Anti-Mexican Discourses in the US}

Most Americans are far from sympathetic to the cause of the immigrantparticularly the immigrant from Latin America, more particularly from Mexico, and even more so, the "illegal" immigrant. We hear anti-immigrant complaints that "they are taking over" American cities, particularly in southern states, that they lower the neighborhood's standard of living, and that they raise the cost of healthcare, since nearly $34 \%$ of immigrants, compared with $13 \%$ of native-born Americans, have no medical insurance, which drives up healthcare costs for everyone else (Camarota, 2007). They overcrowd schools- "illegal immigration" was cited as the number one reason for the overcrowding of LA Unified school district schools in a panel discussion of the education situation there in 1996 ("Inalienable Right?")—and purportedly refuse to learn English. These are common reasons for the sentiment "JUST GO HOME" felt by many US citizens who daily rub shoulders with immigrants - particularly Mexicans-and feel that somehow these immigrants are taking something that is not theirs to take from "us hard-working, god-fearing, taxpaying citizens."

This stigmatizing ideology of Discourses (big D, in Gee's 1990 scheme) in US media (and policy) regarding immigrants, particularly Mexican migrants, has become so naturalized in the US that most citizens take its messages as established fact. Migration (particularly from the south) is traditionally framed as a "problem" even by anthropologists, probably in large part because policy-driven research is not neutral (Castles, 2010). Earlier migration research focused on the problem of Mexicans not assimilating, and there has been a return to "neo-assimilationist approaches" in recent literature (Castles, 2010, p. 1571). Huntington (2004) seems to epitomize nationalist anti-Mexican sentiments about "the Mexican problem" (cited in Smith, 2007, p. 1098), with Mexicans invading the US and refusing to assimilate or speak English. Stephen (2007) attributes the "politics of fear" regarding the border (p. 31), or what Schiller, Basch \& Blanc (1995) call a "bunker mentality" (p. 59), to "border defense groups" like the Minutemen (Stephen, 2007, p. 31). The "Mexican problem" appears at all levels of US society, from national and state immigration and language policies to schools and the deficit theory applied to children of immigrants-multiple and interlinked formulations of the "Mexican problem" that I will attempt to touch on here.

Sociological and anthropological literature also makes it clear that antiimmigrant/anti-Mexican rhetoric and policies are nothing new in the US. De Genova (2002) emphasizes the need to examine "how the historical production of the racialized figure of 'the Mexican' as male 'sojourner' has been rendered synonymous with migrant 'illegality'" (436). In the 1920s (as before and after this period, and as with other racialized groups throughout US immigration history), illegal immig- 
ration was seen as "part of an emergent Mexican 'race problem"' (Ngai, 2004, p. 7), and it was believed that "the narrow frame of 'Americanization' could never assimilate Mexicans as full national citizens: by their language, their ethnic particularity, and their perceived racial difference, working-class Mexicans remained indelibly alien" (Schmidt-Camacho, 2008, p. 28). As far back as 1911, the Dillingham US Immigration Commission announced the following:

Because of their [Mexicans'] strong attachment to their native land, low intelligence, illiteracy, migratory life, and the possibility of their residence here being discontinued, few become citizens of the United States [...] While they are not easily assimilated, this is of no very great importance as long as most of them return to their native land. In the case of the Mexican, he is less desirable as a citizen than as a laborer. (quoted in De Genova, 2002, p. 434)

Thus Mexicans became a distinct group of "undesirables" in the US, and it seems that has not changed much, if the current media and policy rhetoric (particularly in California's Proposition 187 and Arizona's new laws, as well as the trend for such laws increasing in other states) is any indication.

US history attests to public policies decrying the legitimacy of Mexican workers within our borders, when in fact labor and immigration policies encouraged migration northward (Coutin, 2003; Wilson, 1999; De Genova, 2002). Wilson (1999) recounts the major policies scapegoating Mexicans and herding them south: "Since the Great Depression of the 1930s, Mexican laborers have been targeted, stereotyped, blamed and subsequently deported in times of economic crisis" (p. 2). The early "Repatriation Program" herded undocumented Mexican laborers back south. Then "Operation Wetback" shipped them out again during the 1950s recession, with such deportations repeated during the next recession in the 1970s. "Operation Jobs" in the 1980s initiated "raids on workplaces employing Mexican immigrants," with the subsequent deportation of both undocumented immigrants and racially profiled US citizens (Wilson, 1999, p. 2).

Farr (2006) notes wryly that "whenever the 'anti-immigrant' climate in the United States grows, each legislative act intended to curb this migration unintentionally increases it" (p. 57). Other sources confirm this claim (Ngai, 2004; Schmidt-Camacho, 2008; Stephen, 2007). De Genova (2002) discusses the "revolving door policy" of employers and US policy, "whereby mass deportations are concurrent with an overall, large-scale, more or less permanent importation of Mexican migrant labor (citing Cockroft 1986) - for a long time INS split statistics on 'deportable aliens' into 'Mexicans and All Others'” (p. 433). In 1973, 99\% of all deported illegals were Mexican (De Genova, 2002). Surely, though they clearly make up a large percentage of the undocumented, they are not $99 \%$ of it-which suggests racial profiling.

Coutin (2003) notes another paradox in US immigration policies that force migrants into "spaces of nonexistence" (p. 172), tolerating their presence while officially denying it. She notes "underlying tensions" (p. 187) identified by Calavita (1994) which explain this contradiction: employers' demand for cheap labor versus 
employees' demands for fair wages; and the political and logistical unfeasibility of fully enforcing anti-immigration laws. Although it is beyond the scope of this paper to solve the decades-long legal debate over immigration, it is important to understand how national and state policies have permeated the public's perception of workers and families migrating from the south. Mass media messages stir up the anti-immigrant frenzy, as well. Wilson (1999) comments that immigrants have become a convenient target of policy and mass media to avoid tackling the fundamental structural problems of capitalism, for which importing cheap labor is integral.

\section{Terminology}

When discussing immigrants, disparate terms, associations and realities tend to be conflated and muddled together. "Immigrant" emphasizes one-way movement into a receiving country from a sending country, when in fact many Mexican workers are "migrants," moving around the continent for seasonal work and eventually returning to their country (De Genova, 2002). As Mexican communities in the US become more established and grow, while keeping close ties with their home communities, they become "transnational," feet solidly placed in at least two localities. "Illegality" emphasizes the commission of a crime by crossing a border without state-sanctioned papers (or overstaying the expiration date on existing papers), while "undocumented" loses some of the volatility of illegality. "Illegal" or "undocumented" immigrants are usually associated with Mexicans, and Latinos are quickly suspected of illegitimate presence in the US (De Genova, 2002). Even discussing "the immigrant" or "migrant laborers" or "Mexican transnationals" errs by essentializing and homogenizing groups with an objectifying label (De Genova, 2002). All of this is to admit that while we are on terminologically and conceptually shaky ground when discussing the "undocumented immigrant," the focus here is to acknowledge but see past the rhetoric to explore what having "undocumented immigrant" students in our adult ESL classrooms may mean. Throughout this paper I will use the term "immigrant," realizing this may not be accurate in all cases, and the terms "undocumented" and "illegal" interchangeably to mirror the public discourses.

\section{Moving Beyond the Stereotypes}

As neighbors and teachers of immigrants with questionable legal status, we need to "stop regarding the oppressed as an abstract category" [in this case, lumping "immigrants" together with insidious stereotypes] "and see them as persons who have been unjustly dealt with, deprived of their voice, cheated in the sale of their labor" (Freire, 2007, p. 50). Many of my students in a non-credit adult ESL program in Southern California sent money to families at home, while others tried to sustain family who had come with them or joined them here-and yet, even while working 9 to 10 or more hours 6 to 7 days a week, they still valued English enough to come to evening classes 2 to 4 nights a week. Like Rafael in "The Progress of Rafael in English and Family Reading: A Case Study" (Lanteigne \& Schwarzer, 1997), who worked long hours and yet devoted time his own and family members' 
development, my students provided counterexamples to the degrading stereotypes floating around in dominant American cultural scripts. I learned that even undocumented immigrants held stable jobs, sometimes with health benefits and union membership, paid car insurance and taxes, and otherwise lived "god-fearing, law-abiding" lives, aside from the minor detail of lacking the proper "papers." This blatant confrontation to common stereotypes begs questions beyond even those raised by La Ciudad: Why are these people considered such a threat to national security? And if we accept that they are "here to stay," why are we as a nation so reticent to provide them with education and other basic services-some would argue "human rights" (Ticktin, 2006)? Thus the issue I wish to address here is complicated, involving a combination of the stigma, oppression and stereotypes imposed upon Mexican immigrants and the "bad press" undocumented immigrants receive, in addition to questions of educational policy and providing access to "illegals," and the dilemma of how best to serve this demographic in adult education (not to mention K-12) programs.

One of the questions I mention above-why these immigrating hopefuls make such great sacrifices to live such second-class lives in our cities-relates closely to the oppressiveness of their situation. In March 2007, one eighth of residents in the US were immigrants, numbering 37.9 million, and almost one third of these immigrants were undocumented (Camarota, 2007). Over half of the 10.3 million immigrants who entered the US since 2000 are supposedly undocumented, and half of Mexican immigrants are "illegal," comprising an estimated 57\% of the undocumented "aliens" in this country (Camarota, 2007). According to this same report by the Center for Immigration Studies in Washington, DC, 28\% of Mexicans live "in poverty," and $60 \%$ live "in or near poverty," compared with $12 \%$ of "all persons" in poverty and $30.5 \%$ of the general population "in or near poverty" (Camarota, 2007). The report attributes this, as well as the greater use of welfare services and smaller payment of taxes proportionally, to the fact that immigrants from Mexico typically come with only a three-year high school education or less and have larger numbers of dependents (Camarota, 2007). These statistics seem to subtly frame the situation with a xenophobic bent, reflecting the xenophobic, antiMexican discourse that permeates our culture. This also relates to much of the stigma Mexican immigrants must face in the stereotype that they are poor, lowering the general standard of living around them, leeching off the American economy. The above report concludes that granting legal status to undocumented immigrants would likely do little good because of their lower educational attainment. Of course, this would seem to lump all immigrants into the same "boat" with the $57 \%$ of Mexican immigrants who have not finished high school (Camarota, 2007). However, this seems like a huge oversimplification of the problem and its solutions. It of course also views the "immigration problem" in abstract terms, not in terms of its human constituents.

Two tightly knotted issues surrounding the "problem" of "undocumented Mexicans in the US" include (1) the claim that there are so many undocumented immigrants in this country that this is harming our country (overcrowded schools, people who can't function in English, etc.), and (2) the question of whether "illegals" 
have any right to education. For children, the latter was addressed by the Supreme Court Plyler v. Doe decision in 1982, which argued that children should not have to pay for "the sins of their parents" and that "equal protection' under the Fourteenth Amendment 'is not confined to the protection of citizens'" (Stewart, 1993, p. 38). The majority opinion stated, "we cannot ignore the significant cost of social costs borne by our Nation when select groups are denied the means to absorb the values and skills upon which our social order rests" (quoted in Stewart, p. 39). This statement acknowledges the sociocultural capital inherent in school-taught literacy that enables people to function in a domain-in this case, in American schools, workplaces, and society in general (Bourdieu; Marsh, 2006; Compton-Lilly, 2007). As Gutierrez \& Orellana (2006) note regarding the "cultural deprivation" theory, "differences are never just difference; they will always be interpreted and ranked according to dominant cultural values and norms" (p. 506), and immigrant children "different" from dominant culture students will thus be stigmatized for life (Stewart, 1993).

However, this Supreme Court ruling has been challenged and overturned in some states. This goes back to issue \#1 above, blaming overcrowding in schools on massive illegal immigration. For instance, in California, "on education alone the state is spending close to $\$ 2$ billion this year to school 380,000 illegal immigrant children," and illegal immigration in this transcript is claimed to be the "No. 1 reason that Los Angeles Unified School District schools are overcrowded" (Kaye, 1996). This claim again reflects the kind of anti-immigrant sentiment that circulates around our society as the power in discourse that Foucault describes (1990/1978), or Gee's (1990) "Discourse." One "solution" proposed to the issue of undocumented children in schools is that parents be pursued and deported (and the children will follow) rather than enforcing immigration laws in schools (Kaye, 1996). Clearly, recent changes in Arizona law and bills in Indiana, as well as other states, are dealing a heavy hand to both the documented and undocumented in those states, further complicating this situation.

Regarding the education of adults, in the 1980s the Carter administration created an amnesty immigration measure-the Immigration Reform \& Control Act (IRCA) - requiring that illegals only take forty hours of ESL to qualify for amnesty (legal residence in the US; Perlmutter, 1999). That measure is no longer in place, although, as in the "don't ask, don't tell" policy in LA public schools, adult schools also have a long tradition of not asking students' legal status. Now, arguments against the education of undocumented adults include the cost, overcrowding of schools, and long wait lists. Arguments for educating "illegals": they are here, and that is the reality. According to one researcher, "English proficiency among immigrants is linked to higher earnings and tax contributions, lower welfare dependency and greater educational and economic advancement in the second generation"-greater economic capital, in Bourdieu's paradigm - "It's not just a cost. [...] There are returns on this investment"' (quoted in Brulliard, 2007). (Although this quote refers to second-generation immigrants, the principle could readily extend to first generation immigrants). Even with hyper-vigilant enforcement, not all of the many illegals who have entered the US since 2000 will be 
caught. What they need-and if we are honest, what we need for them-is that they can be functioning members of society-which in general entails speaking English.

\section{Immigrants in the Adult ESL Classroom}

ESL teachers of adult immigrants tend to see their role as helping students improve traditional literacy skills and improve scores on the CASAS (Comprehensive Adult Student Assessment System) test-which, incidentally, was the primary IRCA indicator that students had achieved the English level needed to get the green card when that policy was in place (Ferguson, 1998). Even the desire to help immigrants assimilate into the new culture can cause symbolic violence to students (Bourdieu, as discussed in Compton-Lilly, 2007)-or, in Freirean terms, this can be a form of "cultural invasion" in which "the oppressed become convinced of their intrinsic inferiority" linguistically, culturally, and so forth (2007, p. 153). Adult ESL teachers-consciously or subconsciously-often frame lessons in terms of assimilation, when in fact they are imposing their own "world view upon" their students (Freire, 2007, p. 160). However, rather than "teaching with the goal of having students register progress on discrete measures," teachers must "desire to speak to students' cultural identities [and] honor the realities of their lives" (Campano, 2007, p. 4). Rather than "brand[ing]" our literacy level students as "'illiterate' or 'subliterate"' (Campano, p. 13), we must come to recognize and value the "life experiences, values, and literate practices" of our students, helping these students to "become more effective agents in their own educational development" (p. 14). In Freirean terms, this means engaging our students in dialog toward transformation (2007/1970).

\section{Critical Pedagogical Approaches: Finding the Right Balance}

This is not to suggest that guiding our students toward this Freirean liberation will be easy, straightforward, or even welcomed. Lytle (1993) notes that teacher research is "risky" (p. 20) "profoundly political" (p. 21), and "entail[s] boundary crossings and power negotiations that raise further issues" (p. 23)-all of which apply to the incorporation of critical pedagogy into the classroom. Traditionally, teachers are "well-intentioned bank clerks" who see themselves-and in fact, whom the students likely see as- "depositing" knowledge into the "banks" of student brains (Feire, 2007, p. 74). However, in Feire's view, this hierarchical pedagogy is "dehumanizing" (p. 75). In the Freirean tradition of pedagogy, teachers no longer hold a hierarchical position in the classroom but use a "friendship strategy" that allows students to question without fear of being demeaned or shut down (Bartlett, 2005, p. 352). However, the "friendship strategy" is not enough-Bartlett (2005) found limitations in this approach in that students still considered teachers their "superiors" outside of the classroom, and "reduced Freire's complex notion of dialog to a more simplistic ideal of egalitarian classroom discussion" (p. 356), which failed to address "the very social critiques Freire advocated" (p. 359).

The additional Freirean principle of and integrating students' experiences into the classroom-clearly related to the Bourdieuan concept of sociocultural capital and recognizing the capital students bring to the classroom (Compton-Lilly, 
2007; Marsh, 2006), rather than viewing students in terms of their "deficits" (Gutierrez \& Orellana, 2006) - was also oversimplified in practice in Bartlett's (2005) study: teachers generalized immigrants, rather than recognizing their vast diversity; they tried to move students to see the world from their perspectiveclearly not what Freire intended when he said, "Revolutionary leaders cannot think without the people, nor for the people, but only with the people" $(2007$, p. 131). Teachers must become "co-investigators" of problems with their students (Freire, 2007, p. 106), "co-authors of the action that both perform upon the world" (p. 180) open to the "cross-pollination of these two sets of experiences that fuels inquiry" (Campano, 2007, p. 112). Even well-meaning programs seeking to help immigrant adults assimilate through counseling and other extracurricular programs (Szelenyi \& Change, 2002) seem to view students from both deficit model and banking perspectives. How to meet these students' real needs without creating symbolic violence/cultural invasion is tricky, but programs do exist which have done so successfully, such as the Nuevos Horizontes program at Triton College (Illinois), which offers "services including citizenship classes, free legal advice on immigration and naturalization policies, tax preparation assistance, parenting workshops, academic counseling, cultural events," and tutoring, in addition to encouraging the cultural contributions of its Hispanic students (Szelenyi \& Chage, 2002).

Teachers in the Bartlett (2005) study faced other dilemmas, such as encountering student knowledge based on folk wisdom or "knowledge" that countered teachers' own "reverence for official, school knowledge" (p. 359). Clearly, making the shift from a traditional, hierarchical pedagogy to a more egalitarian, dialogical, problem-posing pedagogy is not smooth or unproblematic. Lalik and Oliver (2007) discuss the resistance of Oliver's adolescent students to her agendas (such as extending survey questions to include non-heterosexuals and broadening attraction to go beyond mere appearance) and how teacher and students negotiated and compromised on the curriculum. Oliver had to compromise her agenda by letting what was important to her drop when it was repeatedly rejected by the adolescent girls.

Perhaps a more serious problem would be teachers resistant to incorporating a problem-posing pedagogy in favor of the traditional approaches, simply because those are familiar, comfortable, and secure. However, teachers must realize that they are participating in hegemony, "the process by which we learn to embrace enthusiastically a system of beliefs and practices that end up harming us and working to support the interests of others who have power over us" (Brookfield, 2005, p. 94). Educators who sacrifice their time and energy as a reaction to budget cuts may feel a "private moral commitment" to their "vocation," but they are participating in "a mechanism of control and a prop to the maintenance of the exchange economy" (p. 103). As Freire asserted, teaching, then, is no longer a safe, charitable, neutral vocation, but rather entails a political obligation to empowering students. Educators may in fact be enjoying the "emotional dependence" of the "oppressed" (Freire, 2007, p. 66) without even realizing it. 
Part of empowering students through a "dialogical" approach involves helping them place their situation in "historical context" (Freire, 2007, p. 176). In the general US immigration context, immigrants for centuries have always been "denied full acceptance by public and private institutions, whose leaders insisted they learn English, reject past allegiances, and become totally assimilated" (Perlmutter, 1999, p. 213). As far back as 1919, newspaper editorials criticized the insistence of monolingual "Americanizers" that multi-lingual immigrants speak English and only English (Perlmutter, 1999). No doubt to the vexation of Englishonly enthusiasts, the earliest European immigrants to the United States "were from Spain and not from England in 1598" (Jeria, 1999), which would suggest Spanish as the first non-native colonizing language of this country, not English. Anti-Hispanic sentiment is threaded throughout our history, but not (according to one source) when Hispanics were "viewed as useful resources for economic productivity" (Jeria, 1999)-although I would argue that even when they have been purportedly "welcomed" into this country, the stereotypes and stigmas so deeply embedded in the discourse have persisted. According to Jeria (1999), IRCA "marked a high point of anti-Hispanic sentiment," in addition to the English Only movement countering bilingual education: "English language literacy is driven by labor market needs, as defined by politicians, business leaders, and educators" (Jeria, 1999). This would suggest that even if ESL adult educators have the best intentions of helping their students to adapt to the new culture and attain the needed language skills, they are still just cogs in the machine of dominant discourses (Foucault, 1990), dominant hegemony (Brookfield, 2005), and the "false generosity" of the oppressors (Freire, 2007, p. 146). Thus, as Jeria (1999) notes, "The economic exploitation of Hispanics has shaped a good deal of educational practice toward Hispanics as a group."

\section{Seekers of the American Dream and Holders of Funds of Knowledge}

Not only has exploitation historically existed in education, but also in Mexican experiences in this country in general. For immigrants who risk crossing the border without the proper paperwork, there is "the constant threat of apprehension by the INS" (Brooks, et al., 2007) and by supposed "helpers" (often coyotes who charge border crossers exorbitant fees and then exploit them on top of that). Yet many Mexicans, like the generations of immigrants to the US before them, have embraced the American Dream. Many either hear glorious tales of the good life in the US and move here to improve their lives, only to find themselves in harsh labor situations (like the laborers in La Ciudad), or they plan to come only temporarily to fulfill some financial obligation, and then return to Mexico (Brooks, et al., 2007) - contrary to "leeching and staying indefinitely" stereotypes. Overwhelmingly, though, the Mexicans who crossed the border illegally in one study did so to increase "their children's human capital" (Brooks et al., 2007), which I assume to mean their economic and cultural capital in the US. 
Again, as Freire asserts, it is important to see these cases as humans, not as abstractions. In addition, from the perspective of Moll (1994), many Mexican immigrants possess rich "funds of knowledge" (or in Bourdieu's terms, sociocultural "capital") on which to draw. Funds of knowledge "require specific knowledge of strategic importance to households" (Moll, p. 184), which implies that what knowledge and skills families consider important may differ from what educators and policy makers consider important. These skills include complex social networking far beyond what most US citizens may practice in our competitive, individualistic society, and in Mexican society, this would equal economic capital, not just social/cultural (Bourdieu). As teachers, we need to move beyond the tendency to frame our students in terms of deficit-what they lack (mainly, English and possibly related literacy and job skills) - and to recognize and highlight the strengths they bring to the classroom-lifetimes of experiences, rich linguistic resources, strong motivation, and more.

Ethnographic and sociolinguistic studies have highlighted some of these strengths. For instance, Guerra and Farr, 2002 have demonstrated that in spite of the "literacy crisis" that has been decried in the US for some time, long-term ethnographic work in Chicago with the Mexican community has shown "the creativity, resourcefulness, and substantial capacities that ordinary people demonstrate in their everyday uses of written language (p. 96). Their work may represent one of the few in-depth, long-term transnational sociolinguistic ethnographies conducted with Mexicanos outside the US Southwest. Their work clearly extends from Heath's (1983) famous studies of three communities in one town, exploring the differences between home and school literacy practices and the impact on children's success in school-but with a view toward emphasizing the strengths or "funds of knowledge" (following Moll) or "habitus" (following Bourdieu). Farr (2006) also aims to counter stereotypes homogenizing Mexicans into a single culture, studying the dialects and other indexes of the Rancheros.

Critical Social Theory (CST) offers another pedagogical approach that may tap into these funds of knowledge and enable students to overcome the oppression inherent in their situation. Leonardo (2004) describes CST as "cultivat[ing] students' ability to critique institutional as well as conceptual dilemmas, particularly those that lead to domination or oppression," and in so doing it leads to "knowledge transformation," not "knowledge transmission" (p. 11), as in the banking model that Freire rejected. It seeks to help students free themselves from oppression, and as such, may be known as "sociotherapy" (p. 13). This allusion to psychotherapy brings to mind Rollo May's (1972) Power and Innocence: A Search for the Sources of Violence, essentially a text in psychotherapy, which notes that "The passion for experience is an endeavor to include more of the self in the picture [...] One can, and ought, to reflect on experience" (p. 76). This echoes Freire's relentless call for "the people [to] act, as well as reflect, upon the reality to be transformed" (2007, p. 130). As May notes, "Inherent in power-to-be is the need to affirm one's own being" (1972, p. 137), and so again, immigrants reflecting on their own context within the broader historical context of their situation can enact "transformation." As educators, it is our responsibility to guide our students in becoming successful 
"border crossers" not only literally but metaphorically, as "creative thinkers, decision makers, and transformers of their current life situation" (Ball, 2000, p. 166).

\section{References}

Ball, A. (2000). Empowering pedagogies that enhance the learning of multicultural students. Teachers College Record, 102(6), 1006-1034.

Bartlett, L. (2005). Dialogue, knowledge, and teacher-student relations: Freirean pedagogy and theory in practice. Comparative Education Review, 49(3), 344364.

Brookfield, S. (2005). The power of critical theory for adult learning and teaching. New York: Open University Press.

Brooks, A., Womack, D., Varela, L., Madhlangobe, L., Williams, A., Rodriguez, S., \& Garcia, E. (2007). Mexican perspectives on Mexico-US immigration: Implications for adult education in the U.S \& Mexico [electronic version]. Learning in Community: Proceedings of the Joint International Conference of the Adult Education Research Conference (AERC) (48 th National Conference) and the Canadian Association for the Study of Adult Education CASAE)/l'Association Canadienne pour l'Etude de l'Education des Adultes (ACEEA) (26 ${ }^{\text {th }}$ National Conference).

Brulliard, K. (2007, August 1). English instruction touted for immigrants: Fourfold increase in spending urged. Washington Post, p. A18.

Camarota, S. (2007, November). Immigrants in the United States, 2007: A profile of America's foreign-born population. Backgrounder. Washington DC: Center for Immigration Studies.

Campano, G. (2007). Immigrant students and literacy: Reading, writing, and remembering. New York: Teachers College Press.

Castles, S. (2010). Understanding global migration: A social transformation perspective. Journal of Ethnic and Migration Studies, 36(10), 1565-1586.

Compton-Lilly, C. (2007). The complexities of reading capital in two Puerto Rican families. Reading Research Quarterly, 42(1), 72-98.

Coutin, S. B. (2003). Illegality, borderlands, and the space of nonexistence. In R. Perry \& B. Maurer (Eds.), Globalization under construction (pp. 171-202). Minneapolis: University of Minnesota Press.

De Genova, N. (2002). Migrant "illegality" and deportability in everyday life. Annual Review of Anthropology, 31, 419-447.

Farr, M. (2006). Rancheros in Chicagoacán: Language and identity in a transnational community. Austin: University of Texas Press.

Farr, M., \& Guerra, J. (1995). Literacy in the community: A study of Mexicano families in Chicago. Discourse Processes, 19, 7-19. 
Ferguson, P. (1998). The politics of adult ESL literacy: Becoming politically visible. In T. Smoke (Ed.), Adult ESL: Politics, pedagogy, \& participation in classroom \& community programs (pp. 3-15). Mahwah, NJ: Lawrence Erlbaum.

Foucault, M. (1978/1990). The history of sexuality: An introduction (vol. I). New York: Vintage Books.

Freire, P. (2007). Pedagogy of the oppressed. 30 th anniversary ed. New York: Continuum.

Gee, J. P. (1990). Social linguistics and literacies: Ideology in discourses. London: Falmer.

Guerra, J., \& Farr, M. (2002). Writing on the margins: The spiritual and autobiographical discourse of two Mexicanas in Chicago. In G. Hull \& K. Schultz (Eds), School's out! Bridging out-of-school literacies with classroom practice (pp. 96-123). New York: Teachers College/Columbia University.

Gutierrez, K., \& Orellana, M. (2006). The "problem" of English learners: Constructing genres of difference. Research in the Teaching of English, 40(4), 502-507.

Heath, S. (1983). Ways with words: Language, life, and work in communities and classrooms. Cambridge, UK: Cambridge University Press.

Jeria, J. (1999). The quest for visibility in adult education: The Hispanic experience. Directions for Adult and Continuing Education, 82, 49-65.

Kaye, J. (1996, May 27). Inalienable right? [Transcript of panel discussion]. Los Angeles: KCET-TV.

Lanteigne, B., \& Schwarzer, D. (1997). The progress of Rafael in English and family reading: A case study. Journal of Adolescent and Adult Literacy, 41(1): 36-45.

Leonardo, Z. (2004). Critical social theory and transformative knowledge: The functions of criticism in quality education. Educational Researcher, 33(6), 1118.

Lytle, S. (1993). Risky business. The Quarterly, 15(1), 20-23.

Marsh, J. (2006). Popular culture in the literacy curriculum: A Bourdieuan analysis. Reading Research Quarterly, 41(2), 160-174.

Menard-Warwick, J. (2005). Intergenerational trajectories and sociopolitical context: Latina immigrants in adult ESL. TESOL Quarterly, 39(2), 165-185.

Moll, L. (1994). Literacy research in community and classrooms: A sociocultural approach. In R. Ruddell, M. Ruddell \& H. Singer, Theoretical models \& processes of reading (4th ed.). Newark, DE: IRA. Reprinted in L600 Issues in Language Education, Section 8685 coursepack, pp. 197-207.

Ngai, M. (2004). Impossible subjects: Illegal aliens and the making of modern America. Princeton, NJ: Princeton University Press.

Nieto, S., \& Bode, P. (2008). Affirming diversity: The sociopolitical context of multicultural education. New York: Pearson. 
Perlmutter, P. (1999). Legacy of hate: A short history of ethnic, religious, and racial prejudice in America. New York: Sharpe.

Riker, D. (Dir.) (1999). The City/La Ciudad [DVD]. Originally aired on PBS.

Rollo, M. (1972). Power and innocence: A search for the sources of violence. New York: Delta.

Schiller, N., Basch, L., \& Blanc, C. (1995). From immigrant to transmigrant: Theorizing transnational migration. Anthropological Quarterly, 68(1), 48-63.

Schmidt-Camacho, A. (2008). Migrant imaginaries: Latino cultural politics in the US Mexico borderland. New York: New York University Press.

Stephen, L. (2007). Transborder lives: Indigenous Oaxacans in Mexico, California, and Oregon. Durham, NC: Duke University Press.

Stewart, D. (1993). Immigration and education: The crisis and opportunities. New York: Lexington Books.

Szelenyi, K., \& Chang, J. (2002). Educating immigrants: The community college role. Community College Review, 30(2), 55-73.

Ticktin, M. (2006). Where ethics and politics meet: The violence of humanitarianism in France. American Ethnologist, 33(1), 33-49.

Wilson, T.D. (1999). Anti-immigrant sentiment and the process of settlement among Mexican immigrants to the United States: Reflections on the current wave of Mexican bashing. Review of Radical Political Economics, 31(2), 1-26. 